NBER WORKING PAPER SERIES

\title{
FDI CONTRIBUTION TO CAPITAL FLOWS AND INVESTMENT IN CAPACITY
}

\author{
Assaf Razin \\ Working Paper 9204 \\ http://www.nber.org/papers/w9204 \\ NATIONAL BUREAU OF ECONOMIC RESEARCH \\ 1050 Massachusetts Avenue \\ Cambridge, MA 02138 \\ September 2002
}

The views expressed herein are those of the author and not necessarily those of the International Monetary Fun or the National Bureau of Economic Research.

(C) 2002 by Assaf Razin. All rights reserved. Short sections of text, not to exceed two paragraphs, may be quoted without explicit permission provided that full credit, including $(\mathbb{C}$ notice, is given to the source. 
FDI Contribution to Capital Flows and Investment in Capacity

Assaf Razin

NBER Working Paper No. 9204

September 2002

JEL No. F2, F3

\begin{abstract}
The paper surveys a theory of FDI, which captures a unique feature: hands-on management standards, that enable investors to react in real time to a changing economic environment. Equipped with superior managerial skills, foreign direct investors are able to outbid portfolio investors for the top productivity firms in a particular industry in which they have specialized in the source country. Consequently, FDI investors would make investment, both larger, and of higher quality (namely, with large rates of returns), than the domestic investors. The theory can explain both two-way FDI flows among developed countries, and one-way FDI flows from developed to developing countries. Gains to the host country from FDI stem from the informational value of FDI. The predictions of the theory are consistent with evidence from panel data: larger FDI coefficients in the domestic investment and output growth regressions relative to the portfolio equity flow and international loan coefficients, reflect a more significant role for FDI in the domestic investment process than other types of capital inflows.
\end{abstract}

\author{
Assaf Razin \\ Department of Economics \\ Tel Aviv University \\ Tel Aviv, 69978 \\ Israel \\ and NBER \\ ar256@cornell.edu
}


September 2002

FDI Contribution to Capital Flows and Investment in Capacity

\section{Introduction}

The name "Foreign Direct Investment" usually brings to mind a significant contribution of FDI to domestic investment and to capital inflows. However, there has been a lot of skepticism concerning the contribution of FDI to these engines of growth. As noted by Froot (1993), FDI (the purchase by a domestic resident of a controlling stake in a foreign company) actually requires neither capital flows nor investment in capacity. Conceptually, FDI is an extension of corporate control over international boundaries: "When Japaneseowned Bridgestone takes control over the US firm Firestone, capital need not flow into the US. The equity purchase can largely be financed by US domestic lenders. Any borrowing by Bridgestone from foreign-based third parties also does not qualify as FDI (although it would count as an inflow of portfolio capital into the US). And, of course, in such acquisition there is no investment expenditure; merely an international transfer in the title of corporate assets." Does this example capture the essence of FDI in emerging economies?

The answer we provide in this paper, based on a new theory, and new empirical evidence, is that FDI flows does play an important role in the skimming of high productivity investment projects and thereby contributes significantly to domestic investment in both the quantity and the quality dimensions. 


\section{Old and New Theories}

Theories of FDI can essentially be divided into two categories: micro (industrial organization) theories and macro-finance (cost of capital) theories. The early literature that explains FDI in microeconomic terms focuses on market imperfections, and on the desire of multinational enterprises to expand their market power (see Caves (1971)). Subsequent literature centered more on firm-specific advantages, owing to product superiority or cost advantages, stemming from economies of scale, multi-plants economies and advanced technology, or superior marketing and distribution (see Helpman (1984)). According to this view, multinationals find it cheaper to expand directly in a foreign country, rather than through trade, in cases where the advantages associated with cost or product are based on internal, indivisible assets based on knowledge and technology. Alternative explanations for FDI have focused on regulatory restrictions, including tariffs, quotas, that either encourage or discourage cross-border acquisitions, depending on whether one considers horizontal or vertical integrations.

Studies examining the macroeconomic effects of exchange rate on FDI focussed on the positive effects of an exchange rate depreciation of the host country on FDI inflows, because it lowers the cost of production and investment in the host countries, raising the profitability of foreign direct investment. The wealth effect is another channel through which a depreciation of the real exchange rate could raise FDI. A depreciation of the real exchange rate, by raising the relative wealth of foreign firms, could make it easier for those firms to use retained profits to finance investment abroad and to post a collateral in borrowing from domestic lenders in the host country capital market (see Froot (1991) and Razin and Sadka (2001)). There is also a large literature on different forms of spillovers 
from inward investors in the form of new technologies, new ideas and capital accumulation on the growth of output in the domestic economy. (see Blomstrom, Kokko and Globerman (2001)).

What is the essential difference between portfolio investment and FDI investment from the point of view of corporate governance?

Management under portfolio equity ownership may be plagued by a free-rider problem. Under disperse ownership, if an individual shareholder does something to improve the quality of management, the benefits will accrue also to all other shareholders, see Oliver Hart. In contrast, FDI investor, who is endowed with management skills and gains control of the firm, has better incentives to pursue proper monitoring of management, and will be in better position to micro manage the firm. Furthermore, based on possessing "intangible capital" in her source country, the FDI investor can apply more efficient management standards in the host country compared to domestic investors. Thus, the unique advantage to FDI, that has only recently been explored, is the potential for superior micromanagement, based on the specialization in niches of industry. Important issues with FDI from this standpoint are: (1) Which are the salient characteristics of the free-FDI-flows equilibrium, when FDI investors take control over domestic firms. (2) What constitute the gains from FDI flows to the host economy, given that the foreign investors appropriate the private rewards resulting from their superior management skills; and (3) Whether or not the free-FDI-flows regime is more efficient than free-portfolio-flows regime.

In an integrated capital market, with full information, all forms of capital flows (FDI, loans, and Portfolio equity and debt) are indistinguishable. In the presence of incomplete 
information, these flows are significantly different from one another. In Razin and Sadka (2002), we developed a stylized model of FDI in the presence of imperfect information with respect to the firm's productivity.

We formalized the unique advantage of FDI investment over other types of investment in a stylized model. Suppose that initially all firms are still owned by original (domestic) uninformed owners, and suppose that the productivity shock is purely idiosyncratic. At the beginning of the first period, when investment decisions are made, firms are still uninformed about the productivity shock (the productivity level of the specific firm which they own). It will be revealed only in the second period, when output from new capital becomes public knowledge. In order to make new investment the firm must incur first a fixed setup cost. As the firms are all ex-ante identical, if they have to make the investment decision based on this level of information, they will all invest the same, in accordance with the expected level of the productivity factor. Assume now that at this stage, before the productivity factor is known, foreign direct investors step in. Once acquiring and effectively managing the firm, the FDI investor can better monitor the productivity of the firm than her domestic investor counterpart. She can thus fine-tune the level of capital stock more closely to the value of the productivity factor. Anticipating this fine-tuned investment schedule, the value of the firm to the potential FDI investor is larger than the reservation value to the original owner, and the corresponding bid value to potential domestic investors. Therefore, FDI investors will outbid domestic investors for the firms in the domestic industry. Competition among potential FDI investors will drive up the price close to the price which reflect the upgraded management of the firm. The initial domestic owners will gain the rent, which is equal to difference between the FDI investor's shadow price and the initial owner's reservation price. 
If the competition between potential FDI investors is perfect, all the benefits from the superior FDI management skills accrue to the host economy, leaving the FDI investors with a return on their investment just equalling the world rate of interest. The gains to the host economy from FDI inflows can on this case be classified into two categories. First, there are the conventional gains that stem from opening the economy to the new flow of capital, thereby allowing a more efficient intertemporal allocation of consumption (e.g., via consumption smoothing). Second, there are the intrinsic gains associated with the superior micro-management by FDI investors. The entire gain of the FDI investors is captured by the domestic economy because of assumed perfect competition among these investors over the domestic firms. If, however, there is imperfect competition among FDI investors the gains will split between them and the host country.

The economic gains from FDI, relative to portfolio inflows, lie only in the efficiency of investment, since in both cases there are consumption smoothing effects and the same world interest rate (r) prevails in the host country in both the FDI-flows regime and the Portfolio-flows regime. In other words, the gains from FDI, in comparison to portfolio flows, do not include the traditional gains from opening up the domestic capital market to foreign capital inflows because these traditional gains are present also in the Portfolio-flows regime. Razin and Sadka (2002) were able also to show that, under some plausible conditions on the form of the production function, the size of the aggregate stock of capital is larger under FDI than under Portfolio equity flows.

\section{The Evidence}


Like its theoretical counterpart, empirical work has tended to focus either on underlying factors to explain the location of FDI flows across countries or on explaining the cyclical behaviour of FDI flows using macroeconomic variables, and assessing the contribution of FDI flows to investment and growth.

To what extent is there empirical support for such claims of the significant impact of FDI on domestic investment?

\subsection{Previous Literature}

A comprehensive study by Bosworth and Collins (1999) provides evidence concerning the effect of capital inflows on domestic investment for 58 developing countries during 197895. The authors distinguish among three types of inflows: FDI, portfolio investment, and other financial flows (primarily bank loans). Bosworth and Collins find that an increase of a dollar in capital inflows is associated with an increase in domestic investment of about 50 cents. (Both capital inflows and domestic investment are expressed as percentages of GDP.) This result, however, masks significant differences among different types of inflows. FDI appears to bring about close to a one-for-one increase in domestic investment; there is virtually no discernible relationship between portfolio inflows and investment (little or no impact); and the impact of loans falls between those of the other two. These results hold both for the 58-country sample and for a subset of 18 emerging markets. (See Figure 1; source: Loungani and Razin (2001)).

Figure 1: Estimated Impact of capital flows on domestic investment

Source: Based on Bosworth and Collins (1999). The height of the bar represents the 

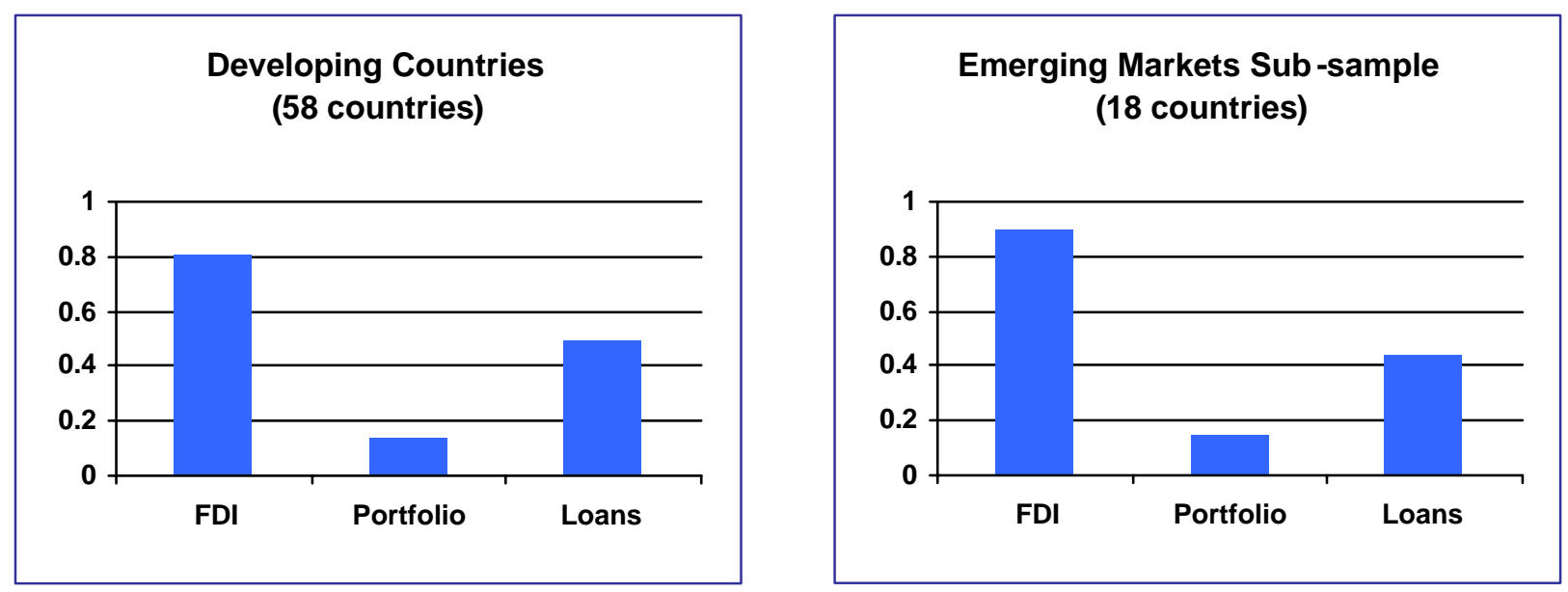

estimated impact of $\$ 1$ of the indicated capital flow on domestic investment.

An additional (striking) feature of FDI flows that was noted in previous literature is that the share of FDI in total inflows is higher in riskier countries, as measured either by countries' credit ratings for sovereign (government) debt or other indicators of country risk (see Figure 2). There is also some evidence that the FDI share is higher in countries where the quality of corporate governance institutions is lower. What can explain these seemingly paradoxical findings? One explanation is that FDI is more likely, compared with other forms of capital flows, to take place in countries with missing or inefficient markets. In such settings, foreign investors will prefer to operate directly instead of relying on local financial markets, suppliers, or legal arrangements.

\subsection{Determinants of FDI Flows: A Gravity Model}

Loungani, Mody, Razin and Sadka (2003) employ a gravity model of bilateral FDI and portfolio capital flows in order to explain determinants of the mobility of financial capital across countries. The authors identify three main categories of variables that significantly explain FDI inflows in the data. First, they find a positive correlation between the degree of industry-specialization in the source countries and FDI flows into the destination 
countries. Second, the ease of communications between the source country and the destination country (as measured by telephone densities in each country) is found to have positive effects on the size of FDI flows. Third, countries with higher debt-equity ratios of publcly traded companies attract less FDI flows; these findings are summarized in Table 1.

In Loungani, Mody, Razin and Sadka (2003) we interpreted the industry-specialization measure in the source country as an indication of a comparative advantage to the potential foreign direct investors in eliciting good investment opportunities in the destination country, relative to domestic investors in the host country. This advantage may stem, for example, from the ability of FDI investors to apply better industry-specific micromanagement standards. In the theory this element is captured by assuming a lower cost of cream (high-productivity-firms)-skimming on the part of foreign direct investors. The second category of variables underscores the role of information as a determinant of FDI inflows. As banks are the main providers of debt capital in emerging markets, and they usually conduct rigorous scrutiny of the credit worthiness of their debtors, we conjecture that, ceteris paribus, firms with high debt-equity ratio tend to be more transparent. In this case, the advantage of FDI investors in their cream-skimming skills (that is, the selection of high productivity firms) is less pronounced and therefore FDI inflows are less abundant. 
Table 1: Determinants of FDI in a Gravity Model

\begin{tabular}{|l|c|}
\hline Host GDP & $\begin{array}{c}0.54 \\
(11.06)\end{array}$ \\
\hline Source GDP & 1.63 \\
& $(20.72)$ \\
\hline Common Language & 0.89 \\
& $(6.72)$ \\
\hline Industry Specialization & 12.05 \\
& $(3.42)$ \\
\hline Specialization > Source GDP & -2.39 \\
& $(-3.56)$ \\
\hline Host Telephone Density & 0.52 \\
& $(9.63)$ \\
\hline Source Telephone Density & 3.52 \\
& $(14.43)$ \\
\hline Host debt-Equity Ratio & -0.005 \\
& $(-3.43)$ \\
\hline Number of Observations & 2326 \\
& $(632)$ \\
\hline
\end{tabular}

$\underline{\text { Notes: }}$

1. Dependent Variable: FDI (real US\$) from source to destination country (1981-1998, three-year averages, using panel tobit method).

2. Source: Loungani, Mody, Razin and Sadka (2002).

\section{FDI Flows, Investment and Growth: Panel Data}

Recently, Hecht, Razin and Shinar (2002) find that the effect of FDI inflows on domestic investment is significantly larger than either portfolio equity or loan inflows; see table 2. They provide also evidence that FDI inflows promote efficiency: The effect of FDI on GDP growth is higher than the effect of other inflows, after controlling for the effect of capital accumulation on GDP growth; see table 3. 
4.1 Empirical Framework for the Panel-Data Analysis

In this sub-section we describe our econometric approach for the estimation of the interactions between domestic investment, FDI flows, international loans, and international portfolio investment. The sample consists of 64 developing countries, including Israel ${ }^{1}$, in the period 1976 to 1997 (22 years in total; see appendix 2). All the variables but the dummies are expressed in terms of gDP percentages. The source of data is the WDI database (see appendix 1). The system of equations is given by:

1. $\mathrm{I}=\beta_{i 1 j}+\beta_{i 2} I(-1)+\beta_{i 3} D Y+\beta_{i 4} D Y(-1)+\beta_{i 5} F D I+\beta_{i 6} P+\beta_{i 6} P+\beta_{i 7} L+\beta_{i 8} G$

2. $\mathrm{FDI}=\beta_{f 1 j}+\beta_{f 2} F D I(-1)+\beta_{f 3} I+\beta_{f 4} D Y+\beta_{f 5} D Y(-1)+\beta_{f 6} \operatorname{Re} s 2$

3. $\mathrm{L}=\beta_{l 1 j}+\beta_{l 2} L(-1)+\beta_{l 3} I+\beta_{l 4} D Y+\beta_{l 5} D Y(-1)$

4. $\quad \mathrm{P}=\beta_{p 1 j}+\beta_{p 2} P(-1)+\beta_{p 3} I+c_{p 4} D Y+\beta_{p 5} D Y(-1)+\beta_{p 6} \operatorname{Re} s 1$

Where,

$\mathrm{I}=$ Gross Domestic Investment $(\%$ of GDP)

FDI $=$ Foreign Direct Investment $(\%$ of GDP $)$

$\mathrm{L}=$ Bank Loans $(\%$ of GDP $)$

$\mathrm{P}=$ Portfolio Investment Flows (\% of GDP)

DY $=$ Annual Percentage Growth Rate of GDP

$\mathrm{G}=$ General Government Consumption (\% of GDP)

Res1 = Multiple Exchange Rates (Single exchange rate $=0$, More than one $=1$ )

1 This section is based on Hecht, Razin and Shinar (2002). 


$$
\begin{aligned}
& \text { Res } 2=\text { Restrictions on Current Account Transactions (No Controls =0, Controls }=1 \text { ) } \\
& \mathrm{j}=\text { Country Index, } \mathrm{j}=01,02,03, \ldots, 64
\end{aligned}
$$

The 4-equation system has four endogenous variables: I, FDI, P and L as dependent variables and observations. Every equation also includes, as an explanatory variable, the dependent variable lagged one period. The exogenous variables used for identification are government expenditure (G), a dummy variable for multiple exchange rates (Res1), a dummy variable for restrictions on current account transactions (Res2), and lagged dependent variables.

Table 2 describes the interactions among the endogenous and the exogenous variables in the 4-equation system.

\begin{tabular}{|c|c|c|c|c|c|c|c|c|c|c|c|c|c|}
\hline \multicolumn{5}{|c|}{ Endogenous Variables } & \multicolumn{9}{|c|}{ Exogenous Variables } \\
\hline & FDI & $\mathrm{P}$ & $\mathrm{L}$ & I & $\mathrm{I}(-1)$ & FDI(-1) & $\mathrm{P}(-1)$ & $\mathrm{L}(-1)$ & DY & $\mathrm{DY}(-1)$ & G & Res2 & Res1 \\
\hline I & + & + & + & & + & & & & + & + & + & & \\
\hline FDI & & & & + & & + & & & + & + & & + & \\
\hline $\mathrm{P}$ & & & & + & & & + & & + & + & & & + \\
\hline $\mathrm{L}$ & & & & + & & & & + & + & + & & & \\
\hline
\end{tabular}

Table 2: Interactions among Endogenous and Exogenous Variables

Two versions are estimated: OLS regressions, as a benchmark, and TSLS regressions with a country-specific effect. To avoid nonstationarity of the residuals in the 4-equation system, we introduce lagged dependent variables on the right hand side of the equation system.

\subsection{Domestic Investment: Findings}


Tables 3-6 present the estimation results, and we discuss them equation-by-equation.

Table 3 describes the effects of capital inflows on domestic investment.

The coefficient of FDI is significant in the OLS and TSLS regressions. FDI long-run effect on domestic investment is 0.94 in the OLS regression and 0.68 in the TSLS regression. Thus, potential for an upward bias in the OLS estimation procedure appears to be validated. Indeed the effect of FDI on domestic investment is smaller in TSLS regressions. The loancoefficient is significant and positive both in the OLS and the TSLS regressions, at a similar magnitude. However, the long run coefficient (adjusted for the lag structure of the regression) moves up from -0.35 in the TSLS regression. The Coefficient of the portfolioinvestment variable is not significant in the OLS regression and becomes significant in the TSLS regression. Interestingly, the long run effect FDI on domestic investment, 0.68 exceeds the corresponding effect of portfolio investment, 0.53 , which in turn exceeds the effect of loans, 0.35. 
Table 3: Determinants of Domestic Investment ${ }^{2}$

\begin{tabular}{lcc}
\hline & OLS & TSLS \\
\hline Foreign Direct Investment, FDI & 0.16 & 0.23 \\
& $(5.2)$ & $(6.8)$ \\
Loan Inflows, L & -0.06 & 0.12 \\
& $(-2.2)$ & $(3.0$ \\
Portfolio Inflows, P & 0.03 & 0.18 \\
& $(0.3)$ & $(2.0)$ \\
Lagged Domestic Investment, I(-1) & 0.87 & 0.66 \\
& $(96.1)$ & $(51.2)$ \\
Output Growth, DY & 0.15 & 0.15 \\
& $(10.4)$ & $(10.9)$ \\
Lagged Output Growth, DY(-1) & & \\
& 0.06 & 0.06 \\
Government Expenditure, G & $(3.8)$ & $(4.4)$ \\
& & \\
$\mathrm{R}_{\text {adj }}^{2}$ & 0.03 & 0.01 \\
Long run effect ${ }^{3}$ of FDI on I & $(2.3)$ & $(0.5)$ \\
Long run effect of P on I & 0.94 & 0.68 \\
& -0.35 & 0.35 \\
& 0.18 & 0.53 \\
& 0.40 & 0.53 \\
\hline
\end{tabular}

* I(-1), FDI, P, L and G are in terms of ratio to GDP, $t$ values appear in parentheses.

\section{$\underline{\text { FDI Inflows }}$}

2 Estimated using Eviews software.

3 The long-term effect expresses the lagged timed structure of the 2SLS estimation. It is calculated as the sum of a converging geometric series: $\beta_{\mathrm{xi}} /\left(1-\beta_{\mathrm{x}(-1) \mathrm{I}}\right)$ 
Table 4 describes the effect of domestic investment on FDI inflows, allowing for the effects of a group of other traditional variables, such as growth, and capital controls.

The coefficient of domestic investment is positive and significant in both the OLS and the TSLS regression. The long-run effect is in the OLS (0.08) is smaller than in the TSLS (0.14).

Table 4: Determinants of FDI Inflows

\begin{tabular}{lcc}
\hline & OLS & TSLS \\
\hline Domestic Investment, I & 0.03 & 0.07 \\
& $(3.0)$ & $(5.0)$ \\
Lagged Foreign Direct Investment, FDI(-1) & 0.60 & 0.50 \\
& $(19.6)$ & $(16.0)$ \\
Output Growth, DY & 0.01 & 0.02 \\
& $(0.10)$ & $(1.6)$ \\
Lagged Output Growth, DY(-1) & -0.01 & 0.02 \\
& $(-0.1)$ & $(1.3)$ \\
Dummy for Capital Controls, Res2 & & \\
(No Controls = 0, Controls $=1)$ & -0.03 & -0.02 \\
Long run effect of I on FDI & $(-2.1)$ & $(-1.2)$ \\
$\mathrm{R}_{\text {adj }}^{2}$ & 0.08 & 0.14 \\
\hline
\end{tabular}

* FDI and I are in terms of ratio to GDP, $\mathrm{t}$ values appear in parentheses.

\section{$\underline{\text { Loan Inflows }}$}


Table 5 describes the effect of domestic investment on loans inflows, allowing for the effect of growth. The coefficient of domestic investment is negative and non-significant in the OLS but positive and significant in the TSLS regression. The long run effect moves up from -0.03 in the OLS regression to 0.08 in the TSLS regression.

Table 5: Determinants of Loans inflows

\begin{tabular}{lcc}
\hline & OLS & TSLS \\
\hline Domestic Investment, I & -0.01 & 0.04 \\
& $(1.4)$ & $(3.0)$ \\
Lagged L, L(-1) & 0.66 & 0.50 \\
& $(22.9)$ & $(16.7)$ \\
Output Growth, DY & 0.01 & -0.001 \\
& $(0.8)$ & $(-0.05)$ \\
Lagged Output Growth, DY(-1) & 0.02 & -0.0002 \\
& $(1.2)$ & $(-0.02)$ \\
Long run effect of I on L & -0.03 & 0.08 \\
$\mathrm{R}_{\text {adj }}^{2}$ & 0.24 & 0.25 \\
\hline
\end{tabular}

* $\mathrm{L}(-1)$ and $\mathrm{I}$ are in terms of ratio to GDP, $\mathrm{t}$ values appear in parentheses.

\section{$\underline{\text { Portfolio Inflows }}$}

Table 6 describes the effect of domestic investment on portfolio investment inflows. The explanatory power of the regression is however poor and most of the right-hand side variables have non-significant coefficients. The regression analysis, effectively, flashes out an auto-correlation process of the portfolio investment flows. 
Table 6: Determinants of PORTFOLIO Investment Inflows

\begin{tabular}{lcc}
\hline & OLS & TSLS \\
\hline Domestic Investment, I & 0.004 & 0.01 \\
& $(0.5)$ & $(0.7)$ \\
Lagged Portfolio Investment, P(-1) & 0.46 & 0.40 \\
& $(4.8)$ & $(4.8)$ \\
Output Growth, DY & 0.001 & -0.001 \\
& $(0.2)$ & $(-0.1)$ \\
Lagged Output Growth, DY(-1) & 0.007 & 0.004 \\
& $(0.5)$ & $(0.3)$ \\
Dummy for Multiple Exchange Rates, Res1 & -0.001 & -0.002 \\
(one exchange rate $=0$, more than one $=1)$ & $(-0.6)$ & $(-0.9)$ \\
& & \\
Long run effect of I on Port & 0.007 & 0.017 \\
$\mathrm{R}_{\text {adj }}^{2}$ & 0.03 & 0.13 \\
\hline
\end{tabular}

* $\mathrm{P}(-1)$ and $\mathrm{I}$ are in terms of ratio to GDP, $\mathrm{t}$ values appear in parentheses.

\subsection{Output Growth: Findings}

The Contribution of Capital Inflows to Output Growth

This section we estimate the contribution of FDI, loans and portfolio investment to output growths. Similarly to the empirical framework in section 3.3.1, the system of equations is given by:

1. $\mathrm{DY}=\beta_{i 1 j} \beta_{i 2} D Y(-1)+\beta_{i e} I+\beta_{i 4} I(-1)+\beta_{i 5} F D I+\beta_{i 6} P+\beta_{i 7} L+\beta_{i 8} G+\beta_{i 9} \operatorname{Ln}(G D P)$ 
2. $\quad \mathrm{FDI}=\beta_{f 1 j}+\beta_{f 2} F D I(-1)+\beta_{f 3} D Y+\beta_{f 4} I+\beta_{f 5} I(-1)+\beta_{f 6} \operatorname{Re} s+\beta_{f 9} \operatorname{Ln}(G D P)$

3. $\left.\mathrm{L}=\beta_{l 1 j}+\beta_{l 2} L 9-1\right)+\beta_{l 3} D Y+\beta_{l 4} I+\beta_{l 5} I(-1)+\beta_{l 9} L n(G D P)$

4. $\quad \mathrm{P}=\quad \beta_{p 1 j}+\beta_{p 2} P(-1)+\beta_{p 3} D Y+C_{p 4} I+\beta_{p 5} I(-1)+\beta_{p 6} \operatorname{Re} s 1+\beta_{p 9} \operatorname{Ln}(G D P)$

Where,

$\mathrm{G}=$ General Government Consumption (\% of GDP)

FDI $=$ Foreign Direct Investment $(\%$ of GDP $)$

$\mathrm{L}=$ Bank loans $(\%$ of GDP)

$\mathrm{P}=$ Portfolio Investment flows (\% of GDP)

$\mathrm{I}=$ Gross Domestic Investment $(\%$ of GDP)

DY = Annual Percentage Growth Rate of GDP

Res1 = Multiple Exchange Rates (single exchange rate $=0$, more than one $=1$ )

Res2 $=$ Restrictions on Current Account Transactions $($ No Controls $=0$, Controls $=1$ )

$\mathrm{Ln}(\mathrm{GDP})=$ The natural logarithm of GDP

$\mathrm{j}=$ Country Index $, \mathrm{j}=01,02,03, \ldots, 64$

Table 7 describes the interactions among the endogenous and the exogenous variable in the 4equation system. 
Table 7: Interactions among Endogenous and Exogenous Variables

\begin{tabular}{|c|c|c|c|c|c|c|c|c|c|c|c|c|c|}
\hline \multicolumn{4}{|c|}{ Endogenous Variables } & \multicolumn{10}{|c|}{ Exogenous Variables } \\
\hline & FDI $\mathrm{P}$ & $\mathrm{L}$ & DY & DY $(-1)$ & FDI(-1) & $\mathrm{P}(-1)$ & $\mathrm{L}(-1)$ & $\operatorname{Ln}(\mathrm{GDP})$ & I & $\mathrm{I}(-1)$ & $\mathrm{G}$ & Res2 & Res 1 \\
\hline I & $+\quad+$ & + & & + & & & & + & + & + & + & & \\
\hline FI & & & + & & + & & & + & + & + & & + & \\
\hline $\mathrm{P}$ & & & + & & & + & & + & + & + & & & + \\
\hline $\mathrm{L}$ & & & + & & & & + & + & + & + & & & \\
\hline
\end{tabular}

\section{$\underline{\text { Output Growth }}$}

Table 7 describes the effects of capital inflows on Growth. The coefficient of FDI is significant in the OLS and TSLS regressions. FDI long-run effect on output GROWTH is 0.1 in the OLS regression and 0.23 in the TSLS regression. The effect of FDI on output growth is smaller in TSLS regressions. Thus, potential for a downward bias in the OLS estimation procedure appears to be demonstrated. The long run coefficient in the TSLS regression is 0.23 .

The loan-coefficient and the portfolio coefficient are not significant in the OLS and the TSLS regressions. However, the long run coefficient of portfolio flows exceeds 0.1. 
Table 8: Determinants of Growth

\begin{tabular}{lcc}
\hline & OLS & TSLS \\
\hline Foreign Direct Investment, FDI & 0.09 & 0.20 \\
& $(3.0)$ & $(5.0)$ \\
Loan Inflows, L & 0.01 & 0.02 \\
& $(0.2)$ & $(0.4)$ \\
Portfolio Inflows, P & 0.05 & 0.10 \\
& $(0.6)$ & $(1.0)$ \\
Lagged Output Growth, DY(-1) & 0.12 & 0.12 \\
& $(7.6)$ & $(6.9)$ \\
Domestic Investment, I & 0.27 & 0.24 \\
& $(14.4)$ & $(11.4)$ \\
Lagged Domestic Investment, I(-1) & -0.22 & -0.18 \\
& $(-12.1)$ & $(-9.1)$ \\
Government Expenditure, G & & \\
Long run effect of P on DY & -0.19 & -0.19 \\
Ln(GDP) & $(-8.4)$ & $(-7.9)$ \\
& & \\
& -0.01 & -0.004 \\
& $(-3.3)$ & $(-1.45)$ \\
& 0.1 & 0.23 \\
& 0.01 & 0.02 \\
& 0.06 & 0.11 \\
& & 0.1 \\
\hline
\end{tabular}

* I(-1), FDI, P, L and G are in terms of ratio to GDP, $\mathrm{t}$ values appear in parentheses.

\section{$\underline{\text { FDI Inflows }}$}

Table 8 describes the effect of output growth on FDI inflows, allowing for the effects of a group of other control variables, such as domestic investment, and capital controls. 
The coefficient of output growth is positive and significant in the TSLS regression. The longrun effect is 0.05 .

Table 9: Determinants of FDI Inflows

\begin{tabular}{lcc}
\hline & OLS & TSLS \\
\hline Output Growth, DY & 0.02 & 0.05 \\
& $(1.3)$ & $(2.2)$ \\
Lagged Foreign Direct Investment, FDI(-1 & 0.45 & 0.49 \\
& $(13.4)$ & $(13.4)$ \\
Domestic Investment, I & 0.07 & 0.08 \\
& $(3.8)$ & $(3.7)$ \\
Lagged Domestic Investment, I(-1) & -0.01 & -0.01 \\
& $(-0.5)$ & $(-0.4)$ \\
Dummy for Capital Controls, Res2 & -0.002 & -0.002 \\
(No Controls = 0, Controls $=1)$ & $(-0.1)$ & $(-0.8)$ \\
Ln(GDP) & & \\
& 0.01 & 0.01 \\
Long run effect of DY on FDI & $(3.5)$ & $(3.0)$ \\
$\mathrm{R}_{\text {adj }}^{2}$ & & \\
\hline
\end{tabular}

* FDI and I are in terms of ratio to GDP, $t$ values appear in parentheses.

\section{$\underline{\text { Loan Inflows }}$}

Table 10 describes the effect of output growth on loans inflows, allowing for the effect of domestic investment. The coefficient of output growth is non-significant in the both regressions. 
Table 10: Determinants of Loans Inflows

\begin{tabular}{lcc}
\hline & OLS & TSLS \\
\hline Output Growth, DY & -0.005 & -0.005 \\
& $(-0.3)$ & $(-0.2)$ \\
Lagged L, L(-1) & 0.49 & 0.49 \\
& $(14.2)$ & $(14.0)$ \\
Domestic Investment, I & 0.06 & 0.07 \\
& $(3.2)$ & $(3.4)$ \\
Lagged Domestic Investment, I(-1) & -0.03 & -0.04 \\
& $(-1.5)$ & $(-1.8)$ \\
Ln(GDP) & -0.01 & -0.01 \\
& $(-2.8)$ & $(-2.3)$ \\
Long run effect of I on L & -0.01 & -0.01 \\
$\mathrm{R}_{\text {adj }}^{2}$ & 0.27 & 0.27 \\
\hline
\end{tabular}

* $\mathrm{L}(-1)$ and $\mathrm{I}$ are in terms of ratio to GDP, $\mathrm{t}$ values appear in parentheses.

\section{$\underline{\text { Portfolio Inflows }}$}

Table 11 describes the effect of output growth on portfolio investment inflows. The explanatory power of the regression is however poor and most of the right-hand side variables have non-significant coefficients. The regression analysis, effectively, flashes out an autocorrelation process of the portfolio investment flows. 
Table 11: Determinants of PORTFOLIO Investment Inflows

\begin{tabular}{lcc}
\hline & OLS & TSLS \\
\hline Output Growth, DY & -0.0004 & 0.003 \\
& $(-0.025)$ & $(0.12)$ \\
Lagged Portfolio Investment, P(-1) & 0.37 & 0.37 \\
& $(3.9)$ & $(3.9)$ \\
Domestic Investment, I & 0.003 & 0.001 \\
& $(0.2)$ & $(0.05)$ \\
Lagged Domestic Investment, I(-1) & 0.01 & 0.01 \\
& $(0.3)$ & $(0.4)$ \\
Dummy for Multiple Exchange Rates, Res1 & -0.002 & -0.002 \\
(one exchange rate $=0$, more than one $=1)$ & $(-0.72)$ & $(-0.6)$ \\
Long run effect of I on Port & 0 & 0 \\
$\mathrm{R}_{\text {adj }}^{2}$ & & \\
\hline
\end{tabular}

* $\mathrm{P}(-1)$ and $\mathrm{I}$ are in terms of ratio to GDP, $\mathrm{t}$ values appear in parentheses.

We summarize the main findings of the panel-data analysis, as follows.

(1) FDI flows have an independent larger effect on domestic investment and output growth than loan flows and portfolio flows (the latter are the least effective).

(2) Among the main determinants of capital inflows, domestic investment, or output growth, have more pronounced effects on FDI inflows, than on loans and portfolio flows. 


\section{Conclusion}

Kindleberger (1969) suggested that in order to think about FDI we must ask not why capital might flow into a country, but rather why some particular asset would be worth more under foreign than under domestic control. I discussed here a theory of FDI, which captures a uniqe feature: hands-on management standards that enable investors to react in real time to a changing economic environment. Equipped with superior managerial skills, foreign direct investors are able to outbid portfolio investors for the top productivity firms in a particular industry in which they have specialized in the source country. Consequently, FDI investors would make investment, both larger, and higher quality, than the domestic investors. The theory can explain both two-way FDI flows among developed countries, and one-way FDI flows from developed to developing countries. Gains to the host country from FDI stem from the informational value of FDI.

The predictions of the theory are consistent with the evidence: larger FDI coefficients in the domestic-investment and output-growth regressions relative to the portfolio equity and international loans inflow coefficients, reflects a unique role for FDI in the domestic investment and growth process.

I would like to end with a cautionary word based on the Irish case. It may be argued that the heavy subsidization of FDI in Ireland in the past two decades resulted in impressive GDP growth, but with less pronounced effect on the well being of Irish residents, as proxied by the Irish GNP growth rates. Gains to the country that serve as host to FDI flows are not necessarily captured by the increase in domestic investment, and productivity, to which FDI flows give rise. 


\section{References}

1) Rui Albuquerque, 2000, "The Composition of International Capital Flows: Risk Sharing through Foreign Direct Investment," Bradley Policy Research Center Working Paper No. FR 00-08 (Rochester, New York: University of Rochester).

2) Blomstrom, M., Kokko, A. and Globerman, S. (2001), "The Determinants of Host Country Spillovers from Foreign Direct Investment: A Review and Synthesis of the Literature," in: Pain, N. (ed.) Inward Investment, Technological Change and Growth: The Impact of Multinational Corporations on the U.K. Economy, Palgrave Press.

3) Eduardo Borensztein, Jose De Gregorio, and Jong-Wha Lee, 1998, "How Does Foreign Direct Investment Affect Growth?" Journal of International Economics, Vol. 45, pp. 115-35.

4) Barry P. Bosworth and Susan M. Collins, 1999, "Capital Flows to Developing Economies: Implications for Saving and Investment," Brookings Papers on Economic Activity:1, Brookings Institution, pp. 143-69.

5) Caves, Richard E., 1971, "International Corporations: The Industrial Economics of Foreign Investment," Economica, Vol. 38 (February), pp. 1-27. 
6) Kenneth A. froot, 1991, "Japanese Foreign Direct Investment," Working Paper No. 3737, issued in June 1991, Published in US-Japan Economic Forum, edited by Martin Feldstein and Kosai.

7) Hart, Oliver (2000), "Financial Contracting," Nancy L. Schwartz Lecture, Kellog Graduate School of Management, Northwestern University.

8) Joel Hecht, Assaf Razin, and Nitsan Shinar, 2002, "Capital Inflows and Domestic Investment: New Econometric Look," mimeo, Bank of Israel.

9) Elhanan Helpman, 1984, A Simple Theory of International Trade with Multinational Corporations, June, Vol. 92, pp. 451-471.

10) Prakash Loungani, Assaf Razin, "How Beneficial Is Foreign Direct Investment for Developing Countries?" Finance and Development, June 2001, Vol. 38, No. 2, pp. 6-10.

11) Prakash Loungani, Ashoka Mody, Assaf Razin, and Efraim Sadka, 2003, The Role of Information in Driving FDI: Theory and Evidence, Paper presented in the North American Winter Meeting of the Econometric Society on January 3-5, 2003.

12) Assaf Razin and Efraim Sadka, 2002, Labor, Capital and Finance: International Flows (New York and Cambridge, England: Cambridge University Press). 
13) Assaf Razin and Efraim Sadka (forthcoming), "Gains from FDI Inflows with Incomplete Information", Economics Letters. 


\section{Appendix 1: List of 64 countries in HRS estimation}

A1.

\begin{tabular}{|c|c|c|c|}
\hline Algeria & Costa Rica & Kenya & Philippines \\
\hline Argentina & Cote d'Ivoire & Korea, Rep. & Rwanda \\
\hline Bangladesh & Dominica & Lesotho & Senegal \\
\hline Belize & Ecuador & Malawi & Sierra Leone \\
\hline Benin & Egypt, Arab Rep. & Malaysia & South Africa \\
\hline Bolivia & Gabon & Mali & Sri Lanka \\
\hline Botswana & Gambia, The & Mauritania & St. Vincent and the Grenadines \\
\hline Brazil & Ghana & Mauritius & Swaziland \\
\hline Burkina Faso & Grenada & Mexico & Syrian Arab Republic \\
\hline Burundi & Guatemala & Morocco & Thailand \\
\hline Cameroon & Guyana & Nepal & Togo \\
\hline Central African Republic & India & Niger & Trinidad and Tobago \\
\hline Chad & Indonesia & Nigeria & Tunisia \\
\hline Chile & Israel & Pakistan & Uruguay \\
\hline Colombia & Jamaica & Papua New Guinea & Zambia \\
\hline Congo, Rep. & Jordan & Peru & Zimbabwe \\
\hline
\end{tabular}

A2.

\section{Sources of data}

The principal source of data is the World Bank WDI 2000 CD-ROM. 
Capital control data was taken from IMF publications.

A few missing data items regarding loans for Israel were taken from the bank of Israel resources.

\section{Definitions of series}

TERMS OF TRADE (DTT) adjustment (constant LCU) (NY.TTF.GNFS.KN) - The terms of trade effect equals capacity to import less exports of goods and services in constant prices. Data are in constant local currency. The change is calculated as the difference from one year to the other.

PUBLIC SPENDING ON EDUCATION (ED3), total (\% of GNP, UNESCO) (SE.XPD.TOTL.GN.ZS) - Public expenditure on education (total) is the percentage of GNP accounted for by public spending on public education plus subsidies to private education at the primary, secondary, and tertiary levels. For more information, see WDI table 2.9.

GDP PER CAPITA (CY), PPP (current international \$) (NY.GDP.PCAP.PP.CD) - GDP per capita based on purchasing power parity (PPP). GDP PPP is gross domestic product converted to international dollars using purchasing power parity rates. An international dollar has the same purchasing power over GDP as the U.S. dollar in the United States. Data are in current international dollars. For more information, see WDI tables 1.1, 4.11, and 4.12. For the estimation we used the logarithm of CY.

FOREIGN DIRECT INVESTMENT (FDI), net inflows (\% of GDP) (BX.KLT.DINV.DT.GD.ZS) - Foreign direct investment is net inflows of investment to 
acquire a lasting management interest (10 percent or more of voting stock) in an enterprise operating in an economy other than that of the investor. It is the sum of equity capital, reinvestment of earnings, other long-term capital, and short-term capital as shown in the balance of payments. For more information, see WDI table 5.1.

GENERAL GOVRNMENT CONSUMPTION (G) (\% of GDP) (NE.CON.GOVT.ZS) General government consumption includes all current spending for purchases of goods and services (including wages and salaries). It also includes most expenditures on national defense and security, but excludes government military expenditures that are part of government capital formation. For more information, see WDI table 4.9.

GROSS DOMESTIC INVESTMENT (I) (\% of GDP) (NE.GDI.TOTL.ZS) - Gross domestic investment consists of outlays on additions to the fixed assets of the economy plus net changes in the level of inventories. Fixed assets include land improvements (fences, ditches, drains, and so on); plant, machinery, and equipment purchases; and the construction of roads, railways, and the like, including commercial and industrial buildings, offices, schools, hospitals, and private residential dwellings. Inventories are stocks of goods held by firms to meet temporary or unexpected fluctuations in production or sales. For more information, see WDI tables 1.4 and 4.9.

GDP GROWTH (DY) (annual \%) (NY.GDP.MKTP.KD.ZG) - Annual percentage growth rate of GDP at market prices based on constant local currency. Aggregates are based on constant 1995 U.S. dollars. For more information, see WDI tables 4.1 and 4.2. 
PORTFOLIO INVESTMENT (P), excluding LCFAR (BoP, current US\$) (BN.KLT.PTXL.CD) - Portfolio investment excluding liabilities constituting foreign authorities' reserves covers transactions in equity securities and debt securities. Data are in current U.S. dollars. This series was divided in the matching GDP to get the portfolio investment as a share of GDP.

BANK AND TRADE-TRADE LENDING (L) (PPG + PNG) (NFL, current US\$) (DT.NFL.PCBO.CD) - Bank and trade-related lending covers commercial bank lending and other private credits. Data are in current U.S. dollars. For more information, see WDI table 6.7. This series was divided in the matching GDP to get the loans flows as a share of GDP.

TOTAL FINACIAL FLOWS (TLY64F - is the sum of FDI, Portfolio \& loans), Total

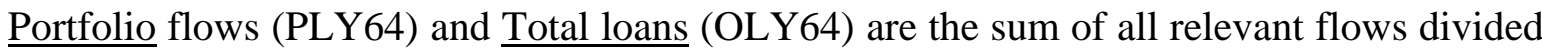
in the sum of relevant GDP. It includes 64 developing countries.

CAPITAL CONTROLS Data on capital controls for all IMF member countries. years: 1966-1997. Dummy takes the value 1 when a restriction is in place, and 0 otherwise.

1) Multiple exchange rates (RES1)

2) Restrictions on current account transactions (RES2)

3) Restrictions on capital account transactions (RES3)

4) Surrender of export proceeds (RES4) 